\title{
6. Analysing urban mobility in ageing populations: the case of two Portuguese historic centres
}

\author{
Anabela Salgueiro Narciso Ribeiro, Fernando \\ Brandão Alves, Ana Maria César Bastos Silva, \\ Sara Santos Cruz, Inês Cunha and João Pedro \\ Martins
}

\subsection{INTRODUCTION}

The promotion of sustainable cities is part of the global agenda, and care for social dimensions (including inclusion and equity) is fundamental to the wellbeing of their inhabitants. This chapter focuses on the trend of the ageing population in the most developed countries, and the needs and conditions of mobility of those who are older, considering that the urban environment and the transport system must be adapted to guarantee these conditions and meet those needs. Projections indicate that, between 2016 and 2060, the proportion of people over 65 will rise from 19.3 per cent to 29.0 per cent of the total population. In the same period, the active population (15-64 years of age) in the European Union is expected to decrease by 11.6 per cent (EC, 2009, 2012). Illustrating this, and according to the National Statistics Institute of Portugal (INE), a ratio of 317 elderly people per 100 young people is expected by 2080 (INE, 2017).

Although this circumstance is a triumph of medical, social and economic development (Ball and Lawler, 2014; Fernández-Ballesteros, 2011; Plouffe and Kalache, 2010) it is simultaneously one of the greatest challenges for public policies (Coughlin, 2017; WHO, 2019; UN, 2019; UNECE, 2019). Recognizing these demographic changes, policies, projects and various initiatives have aimed to adapt to these new circumstances. The role of the United Nations, World Health Organization and the European Commission has been relevant in encouraging the promotion of relevant policies. The increased attention devoted to this type of issue is expressed in some publications, such 
as in Cheng et al. (2019) which analyses how the built environment affects the possibilities of active mobility for the older adults, or in Bergefurt et al. (2019) which highlights the influence of active mobility on their quality of life. Among other contributions, Guo et al. (2019) analyse accessibility to urban parks, one of the essential urban facilities for maintaining active mobility.

The mobility of older adults is particularly difficult in old European urban centres, where roads are often steep, narrow, and have uneven pavements, and where this age group tends to be concentrated, both residents and visitors. This situation is particularly relevant in Southern European cities less affected by the world wars, where various layers of urban structures remain. This happens in almost all the old centres of Portugal. Many of these urban centres have been classified as World Heritage Sites by the United Nations Educational, Scientific and Cultural Organization (UNESCO). This last circumstance often means the impossibility of altering several aspects of the urban space, creating difficulties for local accessibility to public transport and for walking. The elderly are particularly affected by these circumstances. In addition, much of the urban rehabilitation is dedicated to new tourist facilities and not to the urban public space.

The travelling population is also ageing, not only in Portugal, but throughout Europe. The tourist activity, natural in this type of areas, also creates some gentrification problems, and the changes allowed are not always adapted to the needs of visitors or residents. These aspects are presented in the work of Temelová and Dvoráková (2012) showing the consequences of the invasion of tourism in these areas, which affects the lives of the local population, especially the low-income older population with mobility restrictions. Similarly, gentrification also creates problems in Sarajevo, as specified in a work by Pobric and Robinson (2019).

Another characteristic of the mobility of older people, namely in Portugal, is the fact that they usually walk or use public transport, for different reasons, namely because in the past they did not take a driving licence or because they can no longer drive for health or retirement/income reasons. In general, in Portuguese historic urban centres, a large part of the older population has low income and is less likely to own or drive a car. Therefore, the present chapter focuses on the mobility of the elderly in public spaces, and the quality of access to services and transport systems, identifying barriers and motivators both on the side of urban design and on the side of the transport system.

This research focuses on identifying criteria for the establishment of future indexes able to manage and classify urban walking routes and transport systems in terms of quality of mobility and accessibility for all, active and sustainable, assuming that cities more adapted for the older are cities optimized for all citizens. The choice of the Coimbra and Porto case studies is also related to their difficult urban structures and higher ageing problems. 
In terms of structure, this chapter begins with a literature review (section 6.2) on motivators and barriers in pedestrian movements and in the use of public transport by the elderly, dividing the relevant factors into categories of personal characteristics and urban environments (with subcategories). Then, it focuses on the case studies (the cities of Coimbra and Porto), presenting the locations and explaining the interview method and the analysis of the results (sections 6.3 and 6.4). Finally, it ends with some conclusions in view of the initial objectives (section 6.5).

\subsection{LITERATURE REVIEW}

A considerable amount of information already exists showing us that this topic has been growing in importance, mainly in the last decade, due to the growing need to adapt the urban public space to elderly adults' special needs. Urban public spaces must be adapted to the needs of the elderly (Cinderby et al., 2018) to improve the quality of life for this age group and the general population. The perspective of an age-friendly city is therefore influenced by awareness of the impact of an ageing population on urban planning and design (Buffel et al., 2012). Transport is indicated as a key element in this relationship.

Currently, older people tend to remain active. However, this population has specific travel needs, in terms of destinations, travel times and options for modes of transport. Thus, the urban planning of the public urban space and the public transport system that adequately accommodates these needs is fundamental, also contributing to the conditions of an active life, fundamental for all ages. Factors related to the physical environment can make the difference between an elderly person's autonomy and their dependence on others. Thus, it is essential to understand not only the characteristics of the elderly, but also the factors that influence their mobility.

Regarding the main characteristics of trips made by the elderly, we can say that they travel less frequently (Collia et al., 2003; Habib, 2014; Tacken, 1998; Wretstrand et al., 2019; Yang et al., 2018), walk more slowly (it is estimated that while adults aged 25 to 34 years walk at an average speed of around 1.25 $\mathrm{m} / \mathrm{s}$, adults over 64 years walk at $0.96 \mathrm{~m} / \mathrm{s}$, according to a study by de Silva et al. (2014) and travel for a shorter time and distance (Collia et al., 2003; Moniruzzaman et al., 2013; O’Hern and Oxley, 2015; Szeto et al., 2017; Yang et al., 2018). In addition, some factors can be impeding mobility such as living alone (Tacken, 1998), having health problems (Yang et al., 2018), having a low level of education (Tacken, 1998) and having a low income (Habib, 2014).

In addition to the specific characteristics of older adults and their trips which act as factors for or against their mobility - it is important to consider the characteristics that make a city more inclusive, in terms of urban design and also in terms of the transport system. Table 6.1 shows the barriers and 
motivators for pedestrian mobility of the elderly, identified through a systematic analysis of the literature.

Table 6.2 shows the barriers and motivators for mobility using public transport, also identified through the literature.

Previous literature identifies several main motivators and barriers for the mobility of the elderly as pedestrians and public transport users. It identifies common factors valid for all places with characteristics similar to those considered in these case studies of historical city centres. Therefore, the case studies were selected by also taking into account their representativeness, especially considering the similarities of many historic urban centres in Southern Europe.

\subsection{INTERVIEW ANALYSIS}

Portugal follows the ageing trend of the European population. Two case studies were considered, in Coimbra and in Porto, delimiting an area of analysis within their historic centres. These areas have a higher concentration of older residents and both represent critical areas in terms of mobility and accessibility, due to the old and irregular urban structure. In these areas, the car was gradually phased out (more in Porto than in Coimbra) due to some urban rehabilitation projects, and they are still inhabited by a local population mainly formed by older adults, despite the growth in tourism and in visiting population. The urban structure is made up of streets and small, rugged squares, narrow and maintained with old pavements. People travel the areas mainly on foot and using public transport lines, which in the case of Coimbra are mostly composed of small buses that cross its inner areas.

Residents and tourists were interviewed. Participants were chosen from a stratified sample. In the first phase, the city councils responsible for the historical centres (in Coimbra and Porto) were consulted for recommendations on how to interview the older adults who live in those areas. The recommendation was to contact the social institutions that daily support those elderly and where they stay during the day. In a second phase, in those institutions, the social assistants provided indications about the people to be interviewed, selecting those who were in good cognitive condition and/or who still had autonomy to walk and use public transport.

In the case of the residents interviewed, the interviews sought to identify their routines in terms of mobility, covering three main sets of aspects: personal characteristics; motivators and barriers in pedestrian movements; and motivators and barriers in the use of the public transport system. Tourists were interviewed on the street, with the same type of questions. Overall, the interviews in Coimbra and Porto corresponded to a total of 46 respondents, being 24 residents and 22 tourists, 28 women and 18 men, all in the 65 to 95 age group. Regardless of age or gender, or the condition of residents or tourists, the 


\section{Table 6.1 Motivators and barriers in older people's pedestrian movements}

\begin{tabular}{|c|c|c|}
\hline $\begin{array}{l}\text { Factor } \\
\text { types }\end{array}$ & Motivator/barrier & Sample of specific literature \\
\hline \multirow[t]{5}{*}{$\begin{array}{l}\text { Safety } \\
\text { issues }\end{array}$} & Presence of pedestrian paths & $\begin{array}{l}\text { Boarnet et al. (2005), Kerr et al. (2012), Powell et al. } \\
\text { (2003), Southworth (2005) }\end{array}$ \\
\hline & Signal-controlled pedestrian crossings & $\begin{array}{l}\text { Boarnet et al. (2005), Powell et al. (2003), Southworth } \\
\text { (2005) }\end{array}$ \\
\hline & Buffering from road traffic & Powell et al. (2003), Southworth (2005) \\
\hline & Sense of personal safety & $\begin{array}{l}\text { Kerr et al. (2012), Southworth (2005), Gallagher et } \\
\text { al. (2010), Moniruzzaman et al. (2013), Cinderby et } \\
\text { al. (2018), Gómez et al. (2010), Plouffe and Kalache } \\
\text { (2010), Sonmez Turel et al. (2007), Van Cauwenberg } \\
\text { et al. (2012), Wang and Lee (2010) }\end{array}$ \\
\hline & $\begin{array}{l}\text { Enforcement of speeding and other } \\
\text { traffic laws }\end{array}$ & Powell et al. (2003), Southworth (2005) \\
\hline \multirow[t]{2}{*}{ Interac. } & $\begin{array}{l}\text { Availability for shopping/eating/ } \\
\text { recreational activities }\end{array}$ & $\begin{array}{l}\text { Cervero and Duncan (2003), Handy et al. (2002), } \\
\text { Sugiyama et al. (2012) }\end{array}$ \\
\hline & $\begin{array}{l}\text { Opportunities to talk or meet with } \\
\text { friends and neighbours }\end{array}$ & Carver et al. (2005), Krizek (2003) \\
\hline \multirow{3}{*}{$\begin{array}{l}\text { Pleasant/ } \\
\text { visual } \\
\text { qualities }\end{array}$} & $\begin{array}{l}\text { Concern for the natural environment } \\
\text { or 'being green' }\end{array}$ & Nilsson and Kuller (2000) \\
\hline & $\begin{array}{l}\text { Pleasant environment/cleanliness of } \\
\text { neighbourhood and streets }\end{array}$ & $\begin{array}{l}\text { Alfonzo et al. (2008), Handy et al. (2002), Gallagher } \\
\text { et al. (2010), Yung et al. (2016), Feng (2017), Gómez } \\
\text { et al. (2010), Borst et al. (2009), Wang and Lee } \\
\text { (2010), Moniruzzaman et al. (2013), Cinderby et al. } \\
\text { (2018) }\end{array}$ \\
\hline & $\begin{array}{l}\text { A visually appealing environment/ } \\
\text { attractive points }\end{array}$ & $\begin{array}{l}\text { Alfonzo et al. (2008), Kerr et al. (2012), Sugiyama } \\
\text { et al. (2012), Michael et al. (2006), Moniruzzaman et } \\
\text { al. (2015), Van Cauwenberg et al. (2012), Wang and } \\
\text { Lee (2010), Yoo and Kim (2017), Yung et al. (2016), } \\
\text { Feng (2017), Cao et al. (2010), Musselwhite and } \\
\text { Haddad (2010) }\end{array}$ \\
\hline \multirow[t]{3}{*}{ Activity } & Opportunities for exercise & Owen et al. (2004), Suminski et al. (2005) \\
\hline & Easy terrain & $\begin{array}{l}\text { Cervero and Duncan (2003), Dill (2004), Humpel et } \\
\text { al. (2004), Pucher and Buehler (2006) }\end{array}$ \\
\hline & Weather on a given day & $\begin{array}{l}\text { Cervero and Duncan (2003), Dill (2004), Humpel et } \\
\text { al. (2004), Pucher and Buehler (2006) }\end{array}$ \\
\hline
\end{tabular}




\begin{tabular}{lll}
\hline $\begin{array}{l}\text { Factor } \\
\text { types }\end{array}$ & Motivator/barrier & Sample of specific literature \\
\hline & Walking for pleasure & Cao et al. (2010), Gallagher et al. (2010), Plouffe \\
& and Kalache (2010), Wang and Lee (2010), \\
& Moniruzzaman et al. (2015), Borst et al. (2009), \\
& Sonmez Turel et al. (2007), Cinderby et al. (2018) \\
& Cervero and Duncan (2003), Dill (2004) \\
& Distance to destination & Pucher and Buehler (2006) \\
\hline
\end{tabular}

\begin{tabular}{lll} 
Table 6.2 & \multicolumn{1}{c}{$\begin{array}{l}\text { Motivators and barriers for older adults in transport system } \\
\text { use }\end{array}$} & \\
\hline Factor types & Motivator/barrier & Sample of specific literature \\
\hline $\begin{array}{l}\text { Urban } \\
\text { design/urban } \\
\text { environment }\end{array}$ & $\begin{array}{l}\text { Good pedestrian } \\
\text { environment }\end{array}$ & Moniruzzaman et al. (2015), Cinderby et al. (2018) \\
$\begin{array}{l}\text { Public } \\
\text { transport } \\
\text { services }\end{array}$ & Transport availability & Gilhooly et al. (2002), Burkhardt (2003), Banister and \\
& Bowling (2004), Su and Bell (2009), Ipingbemi (2010), \\
& Low travel costs & Wong et al. (2018) \\
& & $\begin{array}{l}\text { Burkhardt (2003), Su and Bell (2009), Olawole and Aloba } \\
\text { (2014), Szeto et al. (2017) }\end{array}$ \\
& Clear information & Ipingbemi (2010), Wong et al. (2018) \\
& Proper vehicle design & Gilhooly et al. (2002), Burkhardt (2003), Ipingbemi (2010), \\
& & Aceves-González et al. (2015), Wong et al. (2017) \\
Safety issues & Personal safety & Gilhooly et al. (2002), Gallagher et al. (2010), Olawole and \\
& & Aloba (2014), Aceves-González et al. (2015) \\
\hline
\end{tabular}

results were aggregated considering motivators and barriers, both for walking and for using public transport.

\subsection{INTERVIEW RESULTS}

The common factors identified in the interviews of both residents and tourists are presented in Table 6.3. The reason for this aggregation has to do with the fact that there are no substantial differences between residents and tourists, except in the case of tourists who noticed, on the one hand, the feeling of good cleanliness and urban security (the residents have a different opinion since they live there permanently) and, on the other hand, the lack of urban signs (not important for residents). It was considered that these differences would not be enough to disaggregate the two groups and, consequently, it was considered that all the factors mentioned should be considered important for the mobility of the older population as a whole. 


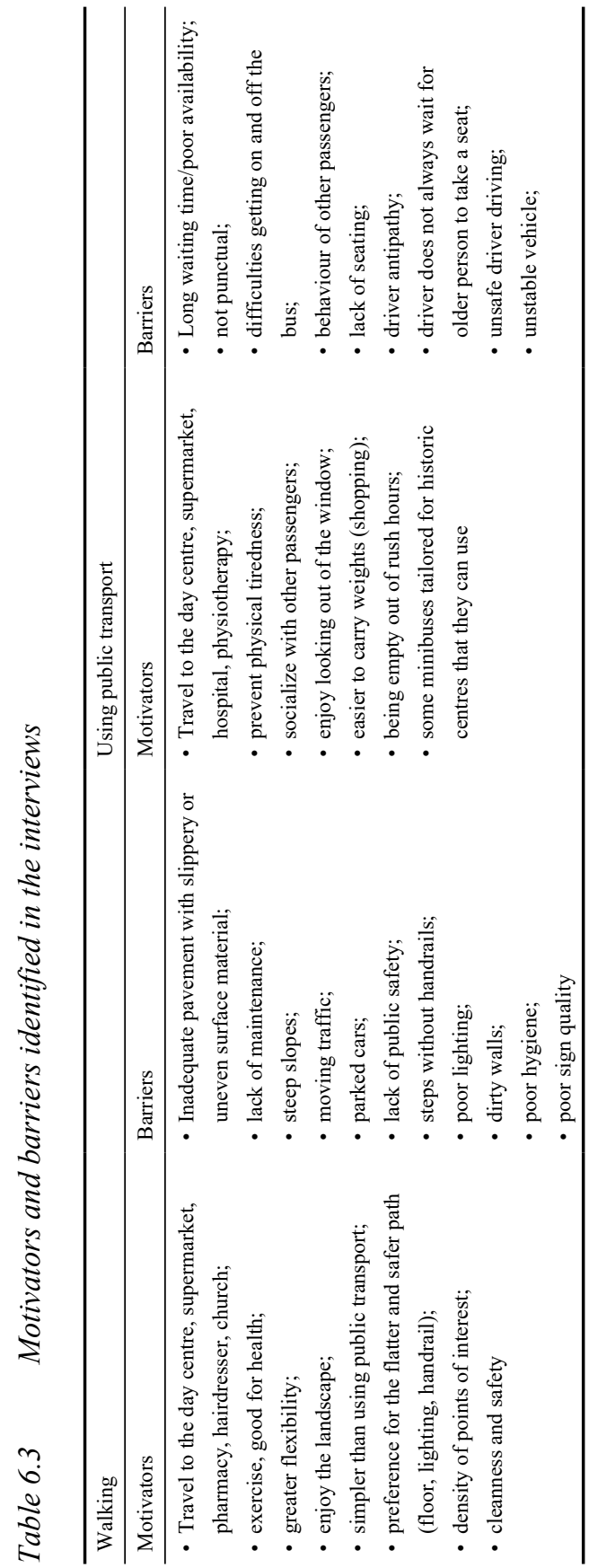


Regarding age, the group interviewed showed good cognitive condition and autonomy to walk and use public transport, and no noticeable differences were found between them, regardless of being 65 or 95 . Considering these results, and cross-checking them with the bibliographic review and with the characterization of the public urban space and the transport system in the two case studies, there is a generalized convergence of what can be the main factors to consider in promoting the mobility of the older population, both in terms of barriers and in terms of motivators.

With regard to pedestrian infrastructure, in particular, reference is made to the lack of some elements of the infrastructure, the inadequacy of physical characteristics and/or the lack of maintenance in relation to pavements with inadequate surfaces, lack of stairs, ramps and handrails (a slope that is too steep and without supports is a central aspect in this analysis). In terms of interaction with other modes of transport, namely with motor vehicles, reference is made to the lack of buffer zones and the prevalence of motor vehicles (moving and parked), increasing the sense of insecurity. Interestingly, the constraints related to intersections between cars and pedestrians are more pressing in the historic centre of Coimbra than in Porto, probably because there has been greater urban regeneration, with the creation of shared spaces in Porto.

In relation to public transport, the interviewees emphasized negative aspects related to human behaviour, such as the performance of public transport drivers and the behaviour of younger travellers, who do not give way to older people. This last aspect may not be specific to the Portuguese case, but it was not identified in previous studies, which is why its detection in this case study was considered interesting.

The interviewees also highlighted the feeling of insecurity caused by walls with offensive graffiti or the lack of public lighting. The feeling of urban insecurity, emphasized by local residents, is based on their contextualized local assessment. Most likely, this is due to age-related vulnerability and not to any real problem of local or regional insecurity. The opposing opinions of tourists give weight to this finding.

\subsection{CONCLUSIONS}

Through this analysis, the identification of common factors that influence the mobility of the older adults will allow the development of planning tools that can help to promote sustainable urban mobility (on foot and by public transport) for adults with increased physical difficulties, being beneficial for all. These instruments should advocate the adaptation of both the public urban space and its multiple infrastructures and the public transport system. The convergence between the factors identified in the literature and the results of the analysis of the case studies allows us to validate those factors to a large extent. 
This analysis also identified other factors related to human behaviour that may be a consequence of the local urban mobility culture itself, which highlights the importance of analyses developed with social proximity, with the public participation of some of those most directly affected by motivators and barriers to mobility in historic urban centres: the still active older adults (much more active than the word 'elderly' makes us think), who are a growing population in the developed world.

\section{ACKNOWLEDGEMENTS}

This work is financially supported by national funds through the FCT/MCTES (PIDDAC), under the MIT Portugal Program under the project MITEXPL/ STS/0065/2017.

\section{REFERENCES}

Aceves-González, C., Cook, S., and May, A. (2015). Bus use in a developing world city: Implications for the health and well-being of older passengers. Journal of Transport and Health, 2(2), 308-316.

Alfonzo, M., Boarnet, M., Day, K., Mcmillan, T., and Anderson, C. (2008). The relationship of neighbourhood built environment features and adult parents' walking. Journal of Urban Design, 13(1), 29-51.

Ball, M.S., and Lawler, K. (2014). Changing practice and policy to move to scale: a framework for age-friendly communities across the United States. Journal of Ageing and Social Policy, 26(1-2), 19-32. https://doi.org/10.1080/08959420.2014 .856706 .

Banister, D., and Bowling, A. (2004). Quality of life for the elderly: the transport dimension. Transport Policy, 11(2), 105-115.

Bergefurt, L., Kemperman, A., van den Berg, P., Borgers, A., van der Waerden, P., et al. (2019). Loneliness and life satisfaction explained by public-space use and mobility patterns. International Journal of Environmental Research and Public Health, 16(21). https://doi.org/10.3390/ijerph16214282.

Boarnet, M., Day, K., Anderson, C., McMillan, T., and Alfonzo, M. (2005). California's Safe Routes to School Program: impacts on walking, bicycling, and pedestrian safety. Journal of The American Planning Association, 71(3), 301-317. doi: 10.1080/01944360508976700.

Borst, H.C., de Vries, S.I., Graham, J.M.A., van Dongen, J.E.F., Bakker, I., and Miedema, H.M.E. (2009). Influence of environmental street characteristics on walking route choice of elderly people. Journal of Environmental Psychology, 29(4), 477-484.

Buffel, T., Phillipson, C., and Scharf, T. (2012). Ageing in urban environments: developing 'age-friendly' cities. Critical Social Policy, 32(4), 597-617.

Burkhardt, J.E. (2003). Better transportation services for older persons. Transportation Research Record: Journal of the Transportation Research Board, 1843(1), 105-112.

Cao, X., Mokhtarian, P.L., and Handy, S.L. (2010). Neighborhood design and the accessibility of the elderly: an empirical analysis in northern California. International Journal of Sustainable Transportation, 4(6), 347-371. 
Carver, A., Salmon, J., Campbell, K., Baur, L., Garnett, S., and Crawford, D. (2005). How do perceptions of local neighborhood relate to adolescents' walking and cycling? American Journal of Health Promotion, 20(2), 139-147.

Cervero, R., and Duncan, M. (2003). Walking, bicycling, and urban landscapes: evidence from the San Francisco Bay area. American Journal of Public Health, 93(9), $1478-1483$.

Cheng, L., Chen, X., Yang, S., Cao, Z., De Vos, J., and Witlox, F. (2019). Active travel for active ageing in China: The role of built environment. Journal of Transport Geography, 76(April), 142-152.

Cinderby, S., Cambridge, H., Attuyer, K., Bevan, M., Croucher, K., et al. (2018). Co-designing urban living solutions to improve older people's mobility and well-being. Journal of Urban Health, 95(3), 409-422.

Collia, D.V., Sharp, J., and Giesbrecht, L. (2003). The 2001 National Household Travel Survey: a look into the travel patterns of older Americans. Journal of Safety Research, 34(4), 461-470.

Coughlin, J.F. (2017). The Longevity Economy: Unlocking the World's Fastest-Growing, Most Misunderstood Market. New York: PublicAffairs.

Dill, J. (2004). Measuring network connectivity for bicycling and walking, TRB 2004 Annual Meeting.

EC (2009). The 2009 ageing report - economic and budgetary projections for the EU-27 Member States (2008-60). https://ec.europa.eu/economy_finance/publications/ pages/publication14992_en.pdf (accessed 3 January 2020).

EC (2012). Active ageing - report. https://ec.europa.eu/commfrontoffice/publicopinion/ archives/ebs/ebs_378_en.pdf (accessed 3 January 2020).

Feng, J. (2017). The influence of built environment on travel behavior of the elderly in urban China. Transportation Research Part D: Transport and Environment, 52, 619-633.

Fernández-Ballesteros, R. (2011). Positive ageing: objective, subjective, and combined outcomes. Electronic Journal of Applied Psychology, 7(1), 22-30.

Gallagher, N.A., Gretebeck, K.A., Robinson, J.C., Torres, E.R., Murphy, S.L., and Martyn, K.K. (2010). Neighborhood factors relevant for walking in older, urban, African American adults. Journal of Ageing and Physical Activity, 18(1), 99-115.

Gilhooly, M., Hamilton, K., O’Neill, M., Gow, J., Webster, N., et al. (2002). Transport and ageing: extending quality of life for older people via public and private transport. Economical and Social Research Council (ERSC) Award Reference Number L480 254025 , East, 44(0), 32.

Gómez, L.F., Parra, D.C., Buchner, D., Brownson, R.C., Sarmiento, O.L., et al. (2010). Built environment attributes and walking patterns among the elderly population in Bogotá. American Journal of Preventive Medicine, 38(6), 592-599.

Guo, S., Song, C., Pei, T., Liu, Y., Ma, T., et al. (2019). Landscape and urban planning accessibility to urban parks for elderly residents: perspectives from mobile phone data. Landscape and Urban Planning, 191(January), 103642.

Habib, K.N. (2014). An investigation on mode choice and travel distance demand of older people in the National Capital Region (NCR) of Canada: application of a utility theoretic joint econometric model. Transportation, 42(1), 143-161.

Handy, S., Boarnet, M., Ewing, R., and Killingsworth, R. (2002). How the built environment affects physical activity. American Journal of Preventive Medicine, 23(2), 64-73. doi: 10.1016/s0749-3797(02)00475-0.

Humpel, N., Owen, N., Iverson, D., Leslie, E., \& Bauman, A. (2004). Perceived environment attributes, residential location, and walking for particular purposes. 
American Journal Of Preventive Medicine, 26(2), 119-125. doi: 10.1016/j. amepre.2003.10.005.

INE (2017) Censos Populacionais. Instituto Nacional de Estatística (Portuguese Nacional Statistics Institute Census).

Ipingbemi, O. (2010). Travel characteristics and mobility constraints of the elderly in Ibadan, Nigeria. Journal of Transport Geography, 18(2), 285-291.

Kerr, J., Rosenberg, D., and Frank, L. (2012). The role of the built environment in healthy aging. Journal of Planning Literature, 27(1), 43-60.

Krizek, K. (2003). Operationalizing neighborhood accessibility for land use-travel behavior research and regional modeling. Journal of Planning Education and Research, 22(3), 270-287.

Michael, Y., Beard, T., Choi, D., Farquhar, S., and Carlson, N. (2006). Measuring the influence of built neighborhood environments on walking in older adults. Journal of Ageing and Physical Activity, 14(3), 302-312.

Moniruzzaman, M., Páez, A., Nurul Habib, K.M., and Morency, C. (2013). Mode use and trip length of seniors in Montreal. Journal of Transport Geography, 30, 89-99.

Moniruzzaman, M., Páez, A., Scott, D., and Morency, C. (2015). Trip generation of seniors and the geography of walking in Montreal. Environment and Planning A, 47(4), 957-976.

Musselwhite, C., and Haddad, H. (2010). Mobility, accessibility and quality of later life. Quality in Ageing and Older Adults, 11(1), 25-37.

Nilsson, M., and Küller, R. (2000). Travel behavior and environmental concern. Transportation Research Part D: Transport and Environment, 5(3), 211-234.

O'Hern, S., and Oxley, J. (2015). Understanding travel patterns to support safe active transport for older adults. Journal of Transport and Health, 2(1), 79-85.

Olawole, M.O., and Aloba, O. (2014). Mobility characteristics of the elderly and their associated level of satisfaction with transport services in Osogbo, Southwestern Nigeria. Transport Policy, 35, 105-116.

Owen, N., Humpel, N., Leslie, E., Bauman, A., and Sallis, J. (2004). Understanding environmental influences on walking. American Journal of Preventive Medicine, 27(1), 67-76. doi: 10.1016/j.amepre.2004.03.006.

Plouffe, L., and Kalache, A. (2010). Towards global age-friendly cities: determining urban features that promote active ageing. Journal of Urban Health, 87(5), 733-739.

Pobric, A., and Robinson, G.M. (2019). Recent urban development and gentrification in post-Dayton Sarajevo, Bosnia and Herzegovina. Cities, 89(February), 281-295.

Powell, K., Martin, L., and Chowdhury, P. (2003). Places to walk: convenience and regular physical activity. American Journal of Public Health, 93(9), 1519-1521

Pucher, J., and Buehler, R. (2006). Why Canadians cycle more than Americans: a comparative analysis of bicycling trends and policies. Transport Policy, 13(3), 265-279.

Silva, A.M.C.B., Cunha, J.R.R., and Silva, J.P.C. (2014). Estimation of pedestrian walking speeds on footways. Proceedings of the Institution of Civil Engineers Municipal Engineer, 167(1), 32-43. DOI: 10.1680/ muen.12.00048.

Sonmez Turel, H., Malkoc Yigit, E., and Altug, I. (2007). Evaluation of elderly people's requirements in public open spaces: a case study in Bornova District (Izmir, Turkey). Building and Environment, 42(5), 2035-2045.

Southworth, M. (2005). Designing the Walkable City. Journal of Urban Planning and Development, 131(4), 246-257.

$\mathrm{Su}, \mathrm{F}$., and Bell, M.G.H. (2009). Transport for older people: characteristics and solutions. Research in Transportation Economics, 25, 46-55. 
Sugiyama, T., Neuhaus, M., Cole, R., Giles-Corti, B., and Owen, N. (2012). Destination and route attributes associated with adults' walking. Medicine and Science in Sports and Exercise, 44(7), 1275-1286. doi: 10.1249/mss.0b013e318247d286.

Suminski, R., Poston, W., Petosa, R., Stevens, E., and Katzenmoyer, L. (2005). Features of the neighborhood environment and walking by US adults. American Journal of Preventive Medicine, 28(2), 149-155.

Szeto, W.Y., Yang, L., Wong, R.C.P., Li, Y.C., and Wong, S.C. (2017). Spatio-temporal travel characteristics of the elderly in an ageing society. Travel Behavior and Society, 9, 10-20.

Tacken, M. (1998). Mobility of the elderly in time and space in the Netherlands: an analysis of the Dutch National Travel Survey. Transportation, 25, 379-393.

Temelová, J., and Dvořáková, N. (2012). Residential satisfaction of elderly in the city centre: The case of revitalizing neighbourhoods in Prague. Cities, 29(5), 310-317.

UN (2019). World Population Ageing 2019. Retrieved from https://www.un.org/ en/development/desa/population/publications/pdf/ageing/WorldPopulation Ageing2019-Highlights.pdf in 3/1/2020.

UNECE (2019). 2018 Active Ageing Index - Analytical Report https://www.unece .org/fileadmin/DAM/pau/age/Active_Ageing_Index/ACTIVE_AGEING_INDEX TRENDS 2008-2016_web_with_cover.pdf (accessed 3 January 2020).

Van Cauwenberg, J., Clarys, P., De Bourdeaudhuij, I., Van Holle, V., Verté, D., et al. (2012). Physical environmental factors related to walking and cycling in older adults: the Belgian ageing studies. BMC Public Health, 12(1), 142.

Wang, Z., and Lee, C. (2010). Site and neighborhood environments for walking among older adults. Health and Place, 16(6), 1268-1279.

WHO (2019). World health statistics 2019: monitoring health for the SDGs, sustainable development goals. Geneva: World Health Organization. License: CC BY-NC-SA 3.0 IGO.

Wong, R.C.P., Szeto, W.Y., Yang, L., Li, Y.C., and Wong, S.C. (2017). Elderly users' level of satisfaction with public transport services in a high-density and transit-oriented city. Journal of Transport and Health, 7(September), 209-217. https://doi.org/10.1016/j.jth.2017.10.004.

Wong, R.C.P., Szeto, W.Y., Yang, L., Li, Y.C., and Wong, S.C. (2018). Public transport policy measures for improving elderly mobility. Transport Policy, 63, 73-79. https://doi.org/10.1016/j.tranpol.2017.12.015.

Wretstrand, A., Svensson, H., Fristedt, S., Falkmer, T., Journal, S., et al. (2019). Older people and local public transit: mobility effects of accessibility improvements in Sweden. Journal of Transport and Land Use, 2(2), 49-65.

Yang, Y., Xu, Y., Rodriguez, DA., Michael, Y., and Zhang, H. (2018). Active travel, public transportation use, and daily transport among older adults: The association of built environment. Journal of Transport and Health, 9, 288-298.

Yoo, S., and Kim, D.H. (2017). Perceived urban neighborhood environment for physical activity of older adults in Seoul, Korea: a multimethod qualitative study. Preventive Medicine, 103, 90-98.

Yung, E.H.K., Conejos, S., and Chan, E.H.W. (2016). Social needs of the elderly and active ageing in public open spaces in urban renewal. Cities, 52, 114-122. 